\title{
Phytochemical and biological investigation on Artocarpus chaplasha Roxb
}

\author{
Sanjida Sharmin, Fakir Shahidullah Tareq, Choudhury \\ Mahmood Hasan and Monira Ahsan \\ Dept. of Pharmacentical Chemistry, Faculty of Pharmacy \\ University of Dhaka, Bangladesh
}

\begin{abstract}
The methanolic extract of the stem bark of Artocarpus chaplasha Roxb. (Family: Moraceae) was investigated for the isolation of pure compounds and determination of few biological activities. A mixture of two compounds cycloartenyl acetate and lupeol acetate were isolated from it. The crude methanol extract as well as its petroleum ether, chloroform, carbon tetrachloride and aqueous soluble fractions were studied for antioxidant, cytotoxic and antimicrobial activities. Among the different fractions, the aqueous soluble partitionate was found to have most potent antioxidant activity as compared to tertbutyl-1hydroxytoluene. Antimicrobial screening of the different fractions was performed using the disc diffusion method. In these tests, the chloroform soluble fraction and carbon tetrachloride soluble fraction of methanolic extract exhibited moderate antimicrobial activity (range of zone of inhibition 8-12 mm). In brine shrimp lethality test, the petroleum ether soluble extract exhibited the highest level of cytotoxicity.
\end{abstract}

Keywords Artocarpus chaplasha; chemical constituents; antioxidant; antimicrobial; cytotoxicity

Paper type Research paper

\section{Introduction}

Artocarpus chaplasha Roxb (Syn: Artocarpus melinoxylus Gagnep.) is a member of the family Moraceae and is native to north-eastern India, lower Burma and the Andaman and Nicobar Islands (Seibert et al., 1991). It is a tall deciduous tree which reaches a height of 30-40 m, with a girth of $3-5 \mathrm{~m}$. The tree has edible fruits. The timber is of good quality and the leaves are used for elephant fodder. They are Perennial plants. Common names of this plant include Chaplash, Chaplis, Chapalis, Lutta, Cham, Sam, Taungpeinne, Toung-peing-nai. Chaplash. It can be found at elevations up to $1650 \mathrm{~m}$. It

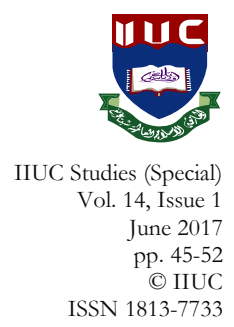




\section{IIUC STUDIES, 14 (Issue 1, Special)}

is adapted to moist conditions and requires a fairly well-marked monsoon climate. The tree is shade-bearing in youth, although it requires a fair amount of light for its later development. Wood production of this tree may be $15-40 \mathrm{~m} 3 / \mathrm{ha} /$ year. Its bark is used to cure skin problems and powdered heals sores. On the other hand, its dry leaves are used to treat swelling of lymph glands. Its fruits help to develop appetite (Nair, Gupta, Das, \& Chakraborti, 2009).

\section{Materials and Method}

\section{a. General experimental procedure}

The ${ }^{1} \mathrm{H}$ NMR spectra were obtained using a Varian Unity 500 spectrometer $(500 \mathrm{MHz})$ instrument in $\mathrm{CDCl}_{3}$. For NMR studies deuterated chloroform was used and the $\delta$ values for ${ }^{1} \mathrm{H}$ spectra were referenced to the residual non deuterated solvent signals.

\section{b. Plant materials collection}

The stem bark of Artocarpus chaplasha Roxb was collected from the Botanical; garden of Dhaka, Bangladesh in November, 2012. A voucher specimen had been maintained in the National herbarium of Bangladesh under the accession number DACB-38271. The bark samples were cut into small pieces and sun dried for 7 days and then dried in oven for 24 hours at $40^{\circ} \mathrm{C}$ to remove moisture completely.

\section{c. Extraction and isolation}

The air-dried and powdered stem bark $(1.3 \mathrm{~kg})$ of Arocarpus chaplasha was soaked in 3L of methanol for 15 days at room temperature and then filtered using a cotton plug, followed by filter paper (Whatman number 1 filter paper).A rotary evaporator was used to remove the solvent and make the solution concentrated. After complete evaporation of the solvent a solid residue of around $14 \mathrm{gm}$ was obtained. Then the sample was subjected to Vacuum liquid chromatography (Pelletier, Chokshi, \& Desai, 1986) for the initial rapid fractionation of the crude methanolic extract. The column was first eluted with $100 \%$ Petroleum ether. Then the polarity of the mobile phases was progressively increased using a increasing concentration of ethyl acetate and passed through the column, until it reached to $100 \%$ ethyl acetate and $0 \%$ petroleum ether. For the initial screening of the VLC fraction extracts Thin layer chromatographic technique (Liu \& LKinderlerer, 1999) was used and the compounds - 1 and 2 (9 mg), were isolated from the VLC extracts of $20 \%$ ethyl acetate in petroleum ether followed by TLC using Merck pre-coated TLC plates (Silica gel 60, F254), eluting with petroleum ether:n-Hexane (40:60). 
An aliquot $(5.0 \mathrm{~g})$ of the concentrated methanolic extract was fractionated by the modified Kupchan partitioning method (VanWagenen et al., 1993) into petroleum ether $(2.0 \mathrm{~g})$, carbon tetrachloride $(0.75 \mathrm{~g})$, chloroform $(0.5 \mathrm{~g})$ and aqueous $(1.75 \mathrm{~g})$ soluble fractions for biological activity.

\section{d. Antioxidant activity}

The antioxidant activities or free radical scavenging activities of the extractives were determined by DPPH assay which was developed by Brand-Williams, Cuvelier, \& Berset, 1995. In this method, 1, 1 diphenyl-2picrylhydrazyl (DPPH) is used to determine free radical scavenging activity. $2.0 \mathrm{ml}$ of different partitionates of methanolic at different concentrations were mixed with $3.0 \mathrm{ml}$ of a DPPH in methanol solution $(20 \mu \mathrm{g} / \mathrm{ml})$. Then the mixtures were kept in dark for 20 minutes for reaction. Finally, absorbance of the different solution was determined at $517 \mathrm{~nm}$ and the inhibition percentage was calculated from the formula: $[(\mathrm{Ao}-\mathrm{A} 1) / \mathrm{Ao}] \times 100$. Here $\mathrm{Ao}=$ the absorbance of the control and $\mathrm{A} 1=$ the absorbance of the test sample.

\section{e. Antimicrobial screening}

The antimicrobial activity of the partitionates against 15 bacteria was evaluated by using disc diffusion method (Bauer, Kirby, Sherris, \& Turck, 1966) (Table-2). Bacteria were collected as pure cultures, from the Institute of Nutrition and Food Sciences (INFS), University of Dhaka, Bangladesh. $400 \mu \mathrm{g} / \mathrm{ml}$ of solutions of test samples (chloroform, aqueous, petroleum ether and carbon tetra-chloride soluble partitionates of methanolic extract) were prepared by dissolving measured amount of the samples in particular volume of respective solvents. Then completely dry and sterilized filter paper discs (6 $\mathrm{mm}$ diameter) were taken and soaked in known amount of the test substance using micropipette and the residual solvents were allowed to evaporate completely. A positive control (standard solution of ciprofloxacin with a concentration of $40 \mu \mathrm{g} / \mathrm{disc}$ ) and negative control (blank discs soaked in respective solvents) were also done. The plates of pure culture impregnated with discs were then allowed to keep at $4^{\circ} \mathrm{C}$ for 24 hours to ensure maximum diffusion of all of the test materials and standard solution. Finally, the plates were incubated at $37^{\circ} \mathrm{C}$ for 24 . Then the diameter of zone of inhibitions were measured in $\mathrm{mm}$ to determine the antimicrobial activity.

\section{f. Evaluation of cytotoxicity}

The general cytotoxic property of the plant extractives were determined 


\section{IIUC STUDIES, 14 (Issue 1, Special)}

using Brine shrimp lethality bioassay (Meyer et al., 1982) (McLaughlin, Rogers, \& Anderson, 1998), technique. In a single day assay, DMSO solutions of the samples were applied against Artemia salina. $4 \mathrm{mg}$ of the extractives were dissolved in DMSO in separate vessels and then solutions of decreasing concentrations $(400,200,100,50,25,12.50,6.25,3.125$, 1.563 and $0.781 \mu \mathrm{g} / \mathrm{ml}$ ) were obtained by serial dilution. In this test, varying concentrations of vincristine sulphate $(10,5,2.5,1.25,0.625$, $0.3125,0.15625,0.078125$ and $0.0390 \mu \mathrm{g} / \mathrm{ml}$ ) were used as positive control.

\section{Results and Discussion}

Compound 1: ${ }^{1} \mathrm{H}$ NMR $\left(500 \mathrm{MHz}, \mathrm{CDCl}_{3}\right): \delta 4.56(1 \mathrm{H}, \mathrm{dd}, \mathrm{J}=9.0,6.5$ $\mathrm{Hz}, \mathrm{H}-3), 0.94$ (3H, s, Me-18), 0.32 (1H, s, Me-19a), 0.56 (1H, s, Me-19b), $0.88(3 \mathrm{H}, \mathrm{d}, \mathrm{J}=9.0 \mathrm{~Hz}, \mathrm{Me}-21), 5.08(3 \mathrm{H}, \mathrm{t}, \mathrm{J}=9.0 \mathrm{~Hz}, \mathrm{Me}-24), 1.67(3 \mathrm{H}$, s, Me-26), 1.59 (1H, s, Me-27), 0.87 (1H, s, Me-28), 0.88 (3H, s, Me-29), 0.83 (3H, s, Me-30), 2.03 (3H, s, Me-2').

Compound 2: ${ }^{1} \mathrm{H}$ NMR $\left(500 \mathrm{MHz}, \mathrm{CDCl}_{3}\right): \delta 4.46(1 \mathrm{H}, \mathrm{dd}, \mathrm{J}=6.0$, $10.5 \mathrm{~Hz}, \mathrm{H}-3), 0.84$ (3H, s, Me-23), 0.83 (3H, s, Me-24), 1.01 (3H, s, Me-25), 0.82 (3H, s, Me-26), 0.77 (3H, s, Me-27), $0.94(1 \mathrm{H}, \mathrm{s}, \mathrm{Me}-28), 4.55(1 \mathrm{H}, \mathrm{s}$, Me-29a), 4.67 (3H, s, Me-29b), 1.67 (3H, s, Me-30), 2.03 (3H, s, Me-2').

Chromatographic separation using VLC and TLC and purification over silica gel of the methanol extract of Artocarpus chaplasha revealed a total of two compounds (1 and 2) in a mixture. The structures of isolated compounds were established by NMR data analysis, comparison with published values and co-TLC with authentic samples.

Mixture of Compound 1 and $2(11 \mathrm{mg})$; was isolated as white powder. Compounds were obtained as white needle from the Gel Permeation column fractions from VLC fraction [n-hexane: Toluene (85: 15)] of crude methanolic extract of Artocarpus chaplasha. It was visualized as a spot undershorts wavelength of UV light $(254 \mathrm{~nm})$. Moreover, It appeared as a purple spot on TLC (silica gel $\mathrm{PF}_{254}$ ) when the plate was sprayed with vanillin sulphuric acid followed by heating at $110^{\circ} \mathrm{C}$ for 3-7 minutes. The $\mathrm{R}_{\mathrm{f}}$ value of the compound was 0.54 in $\mathrm{n}$-Hexane- toluene (85:15) on silica gel $\mathrm{PF}_{254}$ plate. Compounds were found to be soluble in $\mathrm{n}$-Hexane, ethyl acetate and chloroform.

The ${ }^{1} \mathrm{H}$ NMR spectrum (500 $\mathrm{MHz}, \mathrm{CDCl}_{3}$ ) showed two upfield doublets at $\delta$ 0.32and $\delta 0.55$ characteristic of non-equivalent protons of cyclopropyl methylene group and could be ascribed to $19 \mathrm{a}$ and $19 \mathrm{~b}$ respectively. A double doublet at $\delta 4.46$ with a large coupling constant $(3 \mathrm{H}, d d, J=6.0,10.5 \mathrm{~Hz})$ ascribed the $3 \alpha$-proton indicating the presence of acetyl group at $3 \beta$ - position which is further confirmed by the presence 
of methyl group at $\delta 2.03$. The upfield methyl signals were appeared at $\delta$ $0.83, \delta 0.88, \delta 0.87, \delta 0.88$.

The above spectral features are in close agreement to those observed for cycloartenol (Barla \& Irman, 2006) except that instead of H-3 $\alpha$ proton $\delta 3.23$ a deshielded signal at $\delta 4.46$ appeared which is characteristic for the presence of an acetate group on this postion.Further the spectrum showed a triplet at $\delta 5.08$ and two downfield methyls at $\delta 1.67$ and $\delta 1.59$ which could be assigned to $\mathrm{H}-24, \mathrm{Me}-26$ and $\mathrm{Me}-27$ respectively suggesting an unsaturation at $\mathrm{C}-24$. On this basis, the identity the first compound was confirmed as cycloartenyl acetate (1).

The remaining proton signals indicated a lupine triterpene. $T h{ }^{1} \mathrm{H}$ NMR spectrum $\left(500 \mathrm{MHz}, \mathrm{CDCl}_{3}\right.$ ) showed two broad signals at $\delta 4.67$ and $\delta 4.55$ characteristic of exocyclic olefenic protons and could be assigned to $\mathrm{H}-29 \mathrm{~b}$ and H-29a respectively. The tertiary methyl at $\delta 0.84, \delta 0.83, \delta 1.01$, $\delta 0.82, \delta 0.94$ and $\delta 1.67$ could be assigned to Me-24, Me-25, Me-26, Me-27, Me-28 and Me-30 respectively. The $\alpha$-proton at C-3 appeared at $\delta 4.56$ instead of $\delta 3.23$ indicated that $3 \beta \mathrm{OH}$ has been acetylated which is further confirmed by the presence of acetyl methyl at $\delta 2.02$.

On the basis of the above findings the second compound was characterized as lupeol acetate (2) (Jamal, Yaacob, \& Din, 2008).

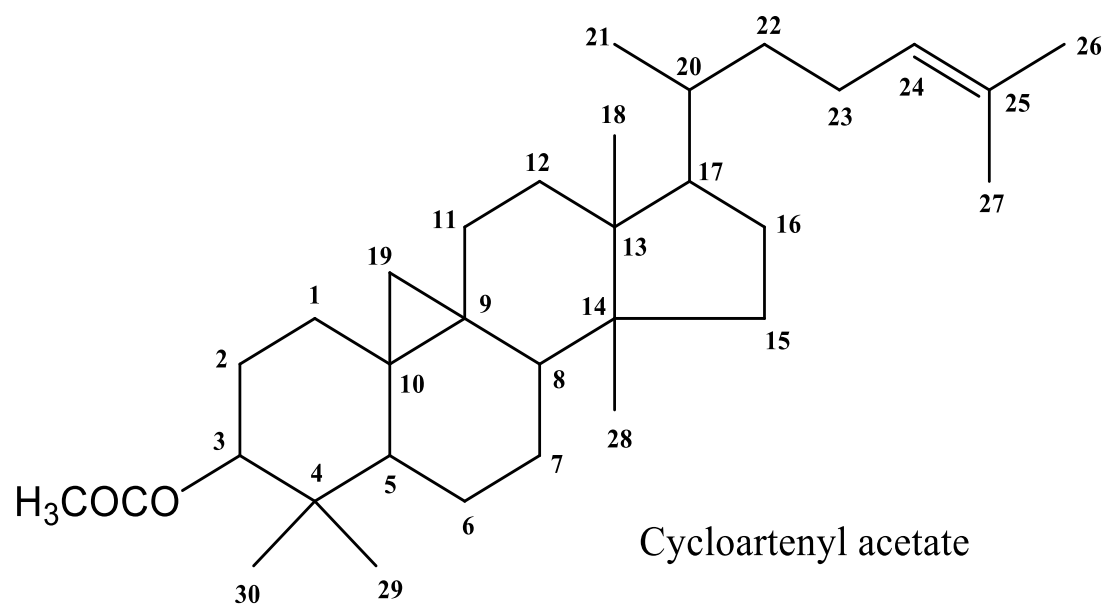




\section{IIUC STUDIES, 14 (Issue 1, Special)}

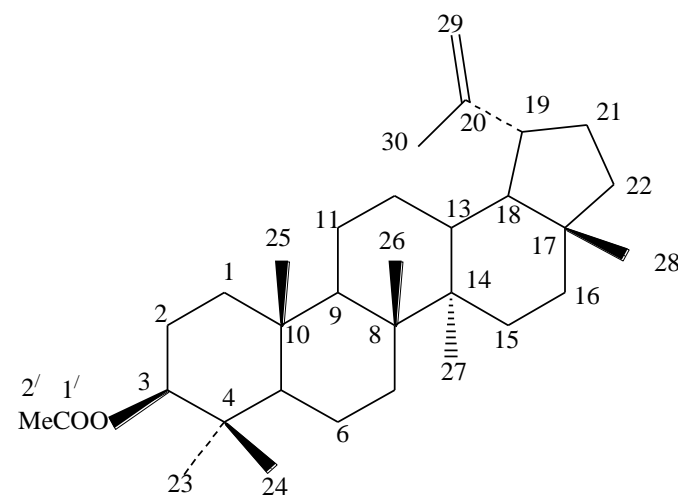

Lupeol acetate (2)

Table-1 : $\mathrm{IC}_{50}$ values of the standard partitionates of Artocarpus chaplasha in DPPH

\begin{tabular}{cc}
\hline Samples & $\mathrm{IC}_{50}$ value $(\mu \mathrm{g} / \mathrm{ml})$ \\
\hline BHT (standard) & 20.96 \\
PEF & 61.12 \\
CTF & 21.52 \\
CLF & 19.20 \\
AQ & 11.54 \\
\hline
\end{tabular}

BHT $=$ Tert- butyl-1-hydroxytoluene

Among the different fractions tested for antioxidant activity (Table i), the aqueous soluble fraction $\left(\mathrm{IC}_{50}=11.54\right)$ of the methanolic extract of $A$. chaplasha showed the highest antioxidant property and other fractions showed moderate free antioxidant property.

In the antimicrobial screening, the methanolic crude extract and its aqueous soluble fractions showed moderate antimicrobial activity with an average zone of inhibition ranging from 10-12 mm each as compared to the standard antimicrobial activity (40-42 $\mathrm{mm}$ ) exhibited by ciprofloxacin (Table ii). However, the chloroform soluble fraction, petroleum ether soluble fraction and the negative control disc did not show any inhibition of microbial growth.

Table-2. Antimicrobial activity of Arocarpus chaplasha extractives and ciprofloxacin

\begin{tabular}{lllllll}
\hline \multirow{2}{*}{ Test organisms } & \multicolumn{6}{c}{ Diameter of the zone of inhibition (mm) } \\
\cline { 2 - 6 } & PE & & CL4 & CL & AQ & Ciprofloxacin \\
\hline Gram positive bacteria & & 8 & 11 & - & 37 \\
Bacillus aureus & - & - & 9 & - & 35 \\
Bacillus megaterium & - & - & - & 9 & - & 45 \\
Bacillus subtilis & - & 7 & 11 & - & 40 \\
Staphylococcus aureus & - & - & - & - & - & 20 \\
Sarcina lutea & - & - & - & - & 40 \\
Bacillus polymyxa & - & - & & & & \\
\hline
\end{tabular}




\begin{tabular}{|c|c|c|c|c|c|}
\hline \multirow{2}{*}{ Test organisms } & \multicolumn{5}{|c|}{ Diameter of the zone of inhibition (mm) } \\
\hline & $\mathrm{PE}$ & CL4 & $\mathrm{CL}$ & AQ & Ciprofloxacin \\
\hline \multicolumn{6}{|l|}{ Gram negative bacteria } \\
\hline Escherichia coli & - & - & - & - & 46 \\
\hline Pseudomonas aureus & - & - & - & - & - \\
\hline Salmonella paratyphi & - & - & - & - & - \\
\hline Salmonella typhi & - & - & - & - & - \\
\hline Shigella boydii & - & - & - & - & 27 \\
\hline Shigella dysenteriae & - & - & - & - & 45 \\
\hline Klebsiella pneumonia & - & - & - & - & 17 \\
\hline Shigella flexi & - & - & 11 & - & - \\
\hline Proteus vulgaris & - & - & 10 & - & 40 \\
\hline
\end{tabular}

The results of brine shrimp lethality testing after 24 hours of exposure to the samples and the positive control, vincristine sulphate are represented in Table iii. The $\mathrm{LC}_{50}$ value was found to be for $1.15 \mu \mathrm{g} / \mathrm{ml}$ petroleum ether fraction and $1.69 \mu \mathrm{g} / \mathrm{ml}$ for aqueous soluble fraction of the methanol as compared to the standard sample, vincristine sulphate $\left(\mathrm{LC}_{50}\right.$ value $\left.=0.451 \mu \mathrm{g} / \mathrm{ml}\right)$.

Table iii. $\mathrm{LC}_{50}$ values of the standard sample and partitionates of Arocarpus chaplasha in brine shrimp lethality assay

\begin{tabular}{lc}
\hline Test Samples & LC $_{50}$ values $(\mu \mathrm{g} / \mathrm{ml})$ \\
\hline VS (standard) & 0.451 \\
PEF & 1.15 \\
CTC & 2.33 \\
CLF & 2.09 \\
AQ & 1.69 \\
\hline
\end{tabular}

Here, $\mathrm{VS}=$ Vincristine sulphate, $\mathrm{PEF}=$ Petroleum ether soluble fraction of the methanolic extract of stem bark of $A$. chaplasha, CTF $=$ Carbon tetrachloride soluble fraction of the methanolic extract of the stem bark of Arocarpus chaplasha, CLF = Chloroform soluble fraction of the methanolic extract, $\mathrm{AQ}=$ Aqueous soluble fraction of the methanolic extract of the stem bark.

\section{Conclusion}

Traditionally used medicinal plants could important sources for the development of potential lead compounds. These lead compounds may be used for the synthesis of new drugs. Our attempt was to identify new compounds in this plant that revealed two compounds and all of them are previously established. Moreover, the crude methanol extract and aqueous soluble fractions of the plant exhibited moderate antimicrobial activity; the aqueous soluble materials demonstrated the highest toxicity and most 


\section{IIUC STUDIES, 14 (Issue 1, Special)}

potent antioxidant activity. This is only a preliminary study and a more detailed study is under progress.

\section{References}

Barla, A., \& Irman, H. B. (2006). Ukran K“ULT"URand Sevil "OKS“UZ. Turk J Chem, 30, 325.

Bauer, A., Kirby, W., Sherris, J., \& Turck, M. (1966). Antibiotic susceptibility testing by a standardized single disc method. Am. J. Clin. Pathol., 45, 493. doi.org/10.1128/AAC.1.6.451

Brand-Williams, W., Cuvelier, M. E., \& Berset, C. (1995). Use of a free radical method to evaluate antioxidant activity. LWT - Food Science and Technology, 28(1), 25-30. doi.org/10.1016/S0023-6438(95)80008-5

Jamal, A. K., Yaacob, W. A., \& Din, L. B. (2008). A chemical study on phyllanthus reticulatus. Journal of Physical Science, 19(2), 45-50.

Liu, Q. T., \& LKinderlerer, J. (1999). Preparative thin-layer chromatographic separation and subsequent gas chromatographic-mass spectrometric analysis of monoacylglycerols derived from butter oil by fungal degradation. Journal of Chromatography A, 855(2), 617-624. doi.org/10.1016/S0021-9673(99)00726-8

McLaughlin, D. J. L., Rogers, L. L., \& Anderson, J. E. (1998). The use of biological assays to evaluate botanicals. Drug Information Journal, 32(2), 513524. doi.org/10.1177/009286159803200223

Meyer, B., Ferrigni, N., Putnam, J., Jacobsen, L., Nichols, D., \& McLaughlin, J. (1982). Brine shrimp: A convenient general bioassay for active plant constituents. Planta Medica, 45(5), 31-34. doi.org/10.1055/s-2007-971236

Nair, D. D., Gupta, A. K., Das, H. B., \& Chakraborti, A. (2009). Medicinal Plants of Tripura. New Delhi: Concept.

Pelletier, S. W., Chokshi, H. P., \& Desai, H. K. (1986). Separation of diterpenoid alkaloid mixtures using vacuum liquid chromatography. Journal of Natural Products, 49(5), 892-900. doi.org/10.1021/np50047a021

Seibert, B., Jansen, P. C. M., Artocarpus, J. R., Forster, G. (1991). In: Verheij, E.W.M., \& Coronel, R. E. (Ed.). Plant Resources of South-East Asia No. 2: Edible fruits and nuts (pp.79-83). The Netherlands : Pudoc: Wageningen.

VanWagenen, B. C., Larsen, R., Cardellina, J. H., Randazzo, D., Lidert, Z. C., \& Swithenbank, C. (1993). Ulosantoin, a potent insecticide from the sponge Ulosa ruetzleri. The Journal of Organic Chemistry, 58(2), 335-337. doi.org/10.1021/jo00054a013

\section{Corresponding author}

Sanjida Sharmin can be contacted at: sharmin.shanjida@gmail.com 